\title{
Analisis Pencatatan dan Pelaporan Penyakit Menular COVID-19 di Wilayah Kecamatan Bangsal Kabupaten Mojokerto dengan Metode Tracing Surveilans
}

\author{
Analysis Recording and Reporting of Infectious Diseases in the Bangsal \\ District Area Using the Tracing Surveillance Method
}

\begin{abstract}
Fahad Sultan Alkatiri*1
ABSTRAK

Latar Belakang: Coronavirus merupakan jenis virus yang menyebabkan penyakit pada manusia dan hewan. Menurut WHO, COVID-19 atau CoronaVirus Disease-2019 adalah penyakit menular yang disebabkan oleh jenis coronavirus yang baru ditemukan yaitu virus severe acute respiratory syndrome coronavirus 2 (SARSCoV-2). WHO menetapkan wabah COVID-19 ini sebagai pandemic, karena telah menyebar keseluruh dunia. Sampai saat ini belum ada vaksin untuk mencegah infeksi Virus Corona atau COVID-19, namun dengan menjalankan protokol kesehatan dengan disiplin dapat memutus rantai penyebaran virus COVID-19.

Tujuan: Menganalisis proses pencatatan dan pelaporan wabah penyakit menular COVID-19 yang dilakukan oleh Surveilans COVID-19 Puskesmas Bangsal.

Metode: Penelitian ini menggunakan metode pencatatan dan pelaporan dengan menelusuri orang yang terkonfirmasi COVID-19 dan mungkin telah melakukan kontak dengan keluarga maupun kerabat yang juga terinfeksi atau telah melakukan perjalanan ke kota yang bestatus zona merah .

Hasil: Tercatat masih banyaknya kasus Orang Dalam Pantauan (ODP) sebanyak 579 orang sejak Maret 2020 Juli 2020, sedangkan kasus konfirmasi positif yang tercatat dari bulan Mei 2020 sampai dengan Agustus 2020 sebanyak 66 orang. Pencegahan penyebaran virus ini bisa dilakukan dengan menjalankan protokol Kesehatan yaitu menggunakan masker, mencuci tangan dengan air bersih, menghindari kerumunan, mengurangi untuk melakukan kontak langsung dengan siapapun dan menjalani hidup sehat dan bersih.

Kesimpulan: Pencatatan dan pelaporan yang dilakukan oleh Puskesmas Bangsal telah sesuai dengan pedoman KepMenkes HK.01.07/2020. Pencatatan kasus COVID-19 dilakukan dengan menggunakan form yang telah ditetapkan oleh Kementrian Kesehatan Republik Indonesia, sedangkan untuk pelaporan terdapat beberapa macam antara lain laporan penemuan kasus, laporan pengiriman dan pemeriksaan spesimen, laporan penyelidikan epidemiologi dan laporan pemantauan kontak erat.
\end{abstract}

Kata kunci : Pencatatan dan Pelaporan, COVID-19, Protokol Kesehatan

\section{ABSTRACT}

Background: Coronavirus is a type of virus that causes disease in humans and animals. According to WHO, COVID-19 or CoronaVirus Disease-2019 is an infectious disease caused by a newly discovered type of coronavirus, namely the severe acute respiratory syndrome coronavirus 2 (SARS-CoV-2). WHO has declared the COVID-19 outbreak a pandemic, because it has spread throughout the world. Until now there is no vaccine to prevent infection with the Corona Virus or COVID-19, but by implementing health protocols with discipline, it can break the chain of spreading the COVID-19 virus.

Objectives: Analyzing the process of recording and reporting COVID-19 infectious disease outbreaks carried out by the Bangsal Health Center COVID-19 Surveillance.

Methods: This study used a recording and reporting method by tracing people who are confirmed to have COVID-19 and may have been in contact with family or relatives who are also infected or have traveled to a city with a red zone status. 
Results: There are still 579 cases of Insider Monitoring (ODP) from March 2020 - July 2020, while positive confirmed cases recorded from May 2020 to August 2020 are 66 people. Prevention of the spread of this virus can be done by implementing Health protocols, namely using masks, washing hands with clean water, avoiding crowds, reducing direct contact with anyone and living a healthy and clean life.

Conclusions: The recording and reporting carried out by the Bangsal Health Center was in accordance with the guidelines of the Minister of Health HK.01.07/2020. The recording of COVID-19 cases is carried out using a form that has been determined by the Ministry of Health of the Republic of Indonesia, while for reporting there are several types, including case finding reports, reports on shipments and examination of specimens, reports on epidemiological investigations and reports on close contact monitoring.

Keywords: Recording and Reporting, COVID-19, Health Protocol

\author{
*Koresponden : \\ fahad.sultan.alkatiri-2015@fkm.unair.ac.id \\ Fahad Sultan Alkatiri \\ ${ }^{1}$ Departemen Epidemiologi, Fakultas Kesehatan Masyarakat, Universitas Airlangga, Kampus C Mulyorejo, \\ 60115, Surabaya, Jawa Timur, Indonesia
}

\title{
PENDAHULUAN
}

Coronavirus merupakan keluarga besar virus yang menyebabkan penyakit pada manusia dan hewan. Pada manusia biasanya menyebabkan penyakit infeksi saluran pernapasan mulai flu biasa hingga penyakit yang serius seperti Middle East Respiratory Syndrome (MERS) dan Sindrom Pernafasan Akut Berat/ Severe Acute Respiratory Syndrome (SARS) (KMK No. HK.01.07-MENKES-413-2020 ttg Pedoman Pencegahan dan Pengendalian COVID-19).

Sebelum terjadinya wabah COVID-19 ada 6 jenis coronavirus yang dapat menginfeksi manusia, yaitu alphacoronavirus 229E, alphacoronavirus NL63, betacoronavirus OC43, betacoronavirus HKU1, Severe Acute Respiratory Illness Coronavirus (SARS-CoV), dan Middle East Respiratory Syndrome Coronavirus (MERS$\mathrm{CoV}$ ). Coronavirus yang menjadi etiologi COVID-19 termasuk dalam genus betacoronavirus (Brooks et al. 2012). Hasil analisis filogenetik menunjukkan bahwa virus ini masuk dalam subgenus yang sama dengan coronavirus yang menyebabkan wabah Severe Acute Respiratory Illness (SARS) pada 2002-2004 silam, yaitu Sarbecovirus. Atas dasar ini, International Committee on Taxonomy of Viruses mengajukan nama SARS-CoV-2 (Coronaviridae Study Group of the International Committee on Taxonomy of Viruses 2020).

Periode inkubasi untuk COVID19 antara 3-14 hari yang ditandai dengan kadar leukosit dan limfosit yang masih normal atau sedikit menurun, serta pasien belum merasakan gejala. Selanjutnya, virus mulai menyebar melalui aliran darah, terutama menuju ke organ yang mengekspresikan ACE2 dan pasien mulai merasakan gejala ringan. Empat sampai tujuh hari dari gejala awal, kondisi pasien mulai memburuk dengan ditandai oleh timbulnya sesak, menurunnya limfosit, dan perburukan lesi di paru. Jika fase ini tidak teratasi dapat terjadi Acute Respiratory Distress Syndrome (ARSD), sepsis, dan komplikasi lain. Tingkat keparahan klinis berhubungan dengan usia (di atas 70 tahun), komorbiditas seperti diabetes, penyakit paru obstruktif kronis (PPOK), hipertensi, dan obesitas (Susilo et al. 2020).

Gejala klinis umum yang terjadi pada pasien COVID-19 diantaranya demam, batuk kering, dispnea, fatigue, nyeri otot, dan sakit kepala (Lapostolle et al. 2020). Berdasarkan penelitian yang dilakukan, gejala klinis yang paling sering terjadi pada pasien COVID-19 yaitu demam (98\%), batuk (76\%), dan myalgia atau kelemahan (44\%). Gejala lain yang terdapat pada pasien, namun tidak begitu sering ditemukan yaitu produksi sputum (28\%), sakit kepala $8 \%$, batuk darah $5 \%$, dan diare $3 \%$. Sebanyak $55 \%$ dari pasien yang diteliti mengalami dispnea (Huang et al. 2020). Sakit abdominal merupakan indikator keparahan pasien dengan infeksi COVID-19. Sebanyak 2,7\% pasien mengalami sakit abdominal, 7,8\% pasien mengalami diare, 5,6\% pasien mengalami mual dan/atau muntah (Suresh Kumar et al. 2020).

Kasus COVID-19 pertama kali ditemukan di Wuhan, China pada Desember 2019. Setiap hari sejak kasus pertama muncul hingga diantara akhir Januari 2020 sampai dengan awal Februari 2020 terjadi peningkatan sebanyak 7.736 kasus terkonfirmasi di China dan 86 kasus terkonfirmasi lainnya terjadi di berbagai negara seperti Taiwan, Thailand, Vietnam, Malaysia, Nepal, Sri Lanka, Kamboja, Jepang, Singapura, Arab Saudi, Korea Selatan, Filipina, India, Australia, Kanada, Finlandia, Prancis, dan Jerman . Pada 12 Maret 2020, WHO mengumumkan COVID-19 sebagai pandemik. Hingga tanggal 29 Maret 2020, terdapat 634.835 kasus dan 33.106 jumlah kematian di seluruh dunia (Satgas COVID19 2020a).

Pada 2 Maret 2020, 2 kasus konfirmasi positif COVID-19 pertama kali diumumkan di Indonesia. Pada 12 Maret 2020, juru bicara untuk COVID-19 mengatakan jumlah pasien kasus virus corona bertambah menjadi 34 
orang, dengan 2 pasien sembuh dan 1 pasien meninggal. Setiap hari terjadi perlonjakan kasus konfirmasi positif COVID-19, hingga pada akhir Maret pertama kali kasus konfirmasi positif melampaui 1.528 kasus dalam waktu sebulan di seluruh Indonesia. Pada akhir April tercatat 10.118 kasus konfirmasi positif COVID-19 dan pada akhir Agustus 2020 tercatat sebanyak 184.268 kasus konfirmasi positif dengan 7.417 pasien dinyatakan sembuh (Satgas COVID19 2020b)

Jawa Timur melaporkan kasus COVID-19 pertama pada tanggal 17 Maret 2020, kasus COVID-19 pertama kali di umumkan oleh Gubernur Jawa Timur. Tercatat sebanyak 6 kasus konfirmasi positif yang berasal dari Surabaya. Pada akhir Maret 2020, kenaikan kasus hingga 93 orang positif COVID-19. Pasien sembuh sebanyak 17 orang dan pasien meninggal sebanyak 8 orang. Sedangkan, pada akhir Juni 2020 tercatat kenaikan kasus konfirmasi COVID-19 yang sangat meningkat sebanyak 11.482 orang. Hingga akhir Agustus 2020, jumlah kasus konfirmasi positif COVID-19 telah mencapai 33.543 pasien, 26.139 pasien dinyatakan sembuh dan 2.370 orang dinyatakan meninggal (Satgas COVID19 Jatim 2020).

Kasus konfirmasi COVID-19 di Mojokerto, pertama kali diumumkan oleh Walikota Mojokerto. Seorang tenaga medis yang bekerja di salah satu fasilitas kesehatan di Kota Surabaya yang pertama kali dinyatakan positif COVID-19. Sedangkan di Kabupaten Mojokerto, kasus pertama adalah seorang ibu rumah tangga. Pada akhir Juni tercatat sebanyak 142 kasus konfirmasi positif COVID-19, 21 pasien dinyatakan sembuh dan 11 pasien meninggal. Hingga akhir Agustus 2020, tercatat 336 kasus terkonfirmasi positif, 279 pasien sembuh dan 18 pasien meninggal (Satgas COVID19 Kota Mojokerto 2020).

Kecamatan Bangsal sendiri, pada 18 Maret 2020 pertama kali melaporkan adanya warga berstatus ODP (Orang Dalam Pengawasan). Tercatat hingga 10 Mei 2020 warga berstatus ODP berjumlah 236 orang, hingga pada tanggal 11 Mei 2020 terkonfirmasi kasus positif COVID-19 pertama. Sumber penularan kasus ini masih belum diketahui pasti, tetapi kasus pertama dikaitkan dengan pasar tradisional Sawahan . Sejak 11 Maret 2020 hingga 11 Agustus 2020 kasus ini meningkat ditandai dengan dilaporkannya sebanyak 66 kasus positif COVID19.

COVID-19 merupakan kondisi yang dianggap baru sehingga berpengaruh terhadap segala hal, termasuk adanya program Puskesmas Bangsal yang baru yaitu program penanggulangan wabah COVID-19 sehingga mengharuskan petugas puskesmas khususnya surveilans untuk memahami pencatatan dan pelaporan kasus COVID-19, dengan menggunakan form yang telah ditetapkan oleh Kementrian Kesehatan sebagai pedoman untuk proses pencatatan dan pelaporan penemuan kasus COVID-19 di Kecamatan Bangsal. Walaupun form yang telah diberikan dirasa baru bagi surveilans, serta jumlah SDM atau petugas untuk proses pencatatan dan pelaporan terbatas sehingga menggangu pelaksaanaannya namun pencatatan pelaporan harus tetap dijalankan untuk melaporkan kasus COVID-19.

Menurut KepMenkes pada HK.01.07/2020 tentang Pencegahan dan Pengendalian COVID-19, Pencatatan dan pelaporan COVID-19 terbagi menjadi laporan notifikasi kasus, laporan pengiriman dan pemeriksaan spesimen, laporan penyelidikan epidemiologi, pelacakan dan pemantauan kontak, dan laporan harian agregat. Secara umum, pencatatan dan pelaporan kasus COVID 19 dilaksanakan 19 terkomputerisasi dengan cara online berbasis aplikasi. Beberapa wilayah yang tidak bisa melaporkan secara online, pengiriman pelaporan dilakukan secara offline menggunakan formulir-formulir terlampir melalui mekanisme yang disepakati. Laporan offline dari fasyankes akan diinput ke aplikasi online oleh dinas kesehatan kabupaten/kota. Aplikasi online yang sudah disiapkan sebagai sistem pencatatan dan pelaporan COVID-19 adalah All Record TC-19 dan Sistem Online Pelaporan Harian COVID19.

Tujuan penelitian ini adalah untuk menganalisis proses pencatatan dan pelaporan wabah penyakit menular COVID-19 yang dilakukan oleh Surveilans COVID-19 Puskesmas Bangsal. Berdasarkan permasalahan diatas, maka dilakukan penelitian untuk menganalisis pencatatan dan pelaporan penyakit menular COVID-19 di wilayah kecamatan Bangsal Kabupaten Mojokerto, dengan tujuan khusus untuk menganalisis pencatatan dan pelaporan COVID-19 menurut pedoman Kepmenkes, menganalisis hambatan yang terjadi dan memberikan rekomendasi dalam permasalahan yang dialami saat proses pencatatan dan pelaporan COVID-19 yang dilakukan oleh Surveilans COVID-19 Puskesmas Bangsal.

\section{METODE}

Penelitian ini merupakan penelitian observasional. Penelitian ini dilakukan di Puskesmas Bangsal yang berada di Kecamatan Bangsal Kabupaten Mojokerto. Waktu kegiatan berlangsung dari 1 Juli 2020 sampai dengan 11 Agustus 2020.

Data diperoleh dari hasil wawancara mendalam dengan petugas surveilans COVID-19 untuk mengetahui pelaksanaan pencatatan dan pelaporan kasus COVID-19 yang dilakukan oleh Puskesmas Bangsal. Analisis dilakukan secara deskriptif dengan pendekatan sistem (input, process, dan output). Input terdiri dari surveilans, form laporan harian, pedoman KepMenkes. Process terdiri dari pengumpulan data, analisis dan interprestasi data dan pelaporan data. Sedangkan output terdiri dari informasi dan indikator kinerja surveilans. 


\section{HASIL DAN PEMBAHASAN}

\section{Gambaran Input \\ Surveilans}

Menurut WHO (2004), Surveilans adalah proses pengumpulan, pengolahan, analisis dan interprestasi data secara sistematik dan terus menerus serta penyebaran informasi kepada unit yang membutuhkan untuk dapat mengambil Tindakan.

Puskesmas Bangsal memiliki Surveilans Epidemiologi yang menangani semua program kegiatan Epidemilogi. Salah satu program yang ditangani oleh surveilans saat ini adalah tentang COVID-19. Surveilans COVID-19 di Puskesmas Bangsal melakukan pengumpulan data, mencatat data, melaporkan hasil penemuan kasus baru dan lain sebagainya.

Berdasarkan hasil wawancara, Surveilans Puskesmas Bangsal berjumlah satu orang dengan pendidikan terakhir S1. Surveilans telah bekerja di Puskesmas Bangsal selama kurang lebih 10 tahun. Surveilans menjalankan semua program kegiatan epidemiologi khususnya penanganan wabah COVID-19. Surveilans Puskesmas Bangsal juga merangkap sebagai petugas pencatatan dan pelaporan COVID-19. Dari hal tersebut, terkadang beberapa kegiatan terkendala termasuk 46 proses pencatatan dan pelaporan terlambat untuk dikerjakan karena kurangnya jumlah surveilans di Puskesmas Bangsal.

\section{Form Laporan Harian}

Laporan harian dikerjakan menggunakan form yang telah ditetapkan oleh Kemenkes. Form laporan harian tersebut dikerjakan setiap hari saat ditemukannya kasus baru COVID-19 maupun saat melakukan pendataan kontak erat (contact tracing) yang kemudian dilanjutkan untuk dilaporkan ke Dinas Kesehatan Kabupaten atau Kota.

Form laporan harian tersebut terdiri dari beberapa jenis form laporan yaitu form laporan pemantauan harian, form laporan penemuan kasus, form laporan penyelidikan epidemiologi, form laporan pengambilan dan pengiriman spesimen, form laporan pelacakan kontak erat, form laporan identifikasi kontak erat, form laporan pendataan kontak erat.

\section{Pedoman KepMenkes HK.01.07/2020}

Kementrian Kesehatan Republik Indonesia telah menyusun pedoman tentang pencegahan dan pengendalian COVID-19 yang dapat digunakan tenaga kesehatan saat menjalankan program pemutusan mata rantau COVID-19. Dalam pedoman KepMenkes tersebut juga terdapat pedoman dalam pencatatan dan pelaporan yang terbagi menjadi laporan notifikasi kasus, laporan pengiriman dan pemeriksaan spesimen, laporan penyelidikan epidemiologi, pelacakan dan pemantauan kontak, dan laporan harian agregat.

\section{Gambaran Process}

Pengumpulan Data

Pengumpulan data yaitu mengumpulkan dan mengukur informasi mengenai variable yang ditargetkan guna menunjang kebutuhan dalam suatu penelitian. Jika ditemukan kasus baru di Kecamatan Bangsal, Puskesmas Bangsal bekerja sama dengan Satgas COVID-19 maupun masyarakat untuk memberikan informasi dan pendataan orang yang terjangkit COVID-19. Adapula pengumpulan data dilakukan dengan pendataan pasien yang datang ke Puskesmas Bangsal dengan gejala COVID-19 maupun dalam kategori rentan untuk tertular COVID-19. Namun, terkadang saat proses pengumpulan data didapatkan hambatan seperti adanya beberapa orang dengan gejala COVID-19 yang enggan memberikan data secara lengkap dikarenakan pemahaman masyarakat tentang COVID-19 yang masih banyak mendapat berita bohong (Hoax). Karena hal tersebut menjadikan proses pelaporan dan rekapan data menjadi terhambat.

\section{Analisis dan Interprestasi Data}

Analisis data adalah proses penyederhanaan data ke dalam bentuk yang lebih mudah dibaca, dipahami dan diinterprestasikan. Data COVID-19 yang telah didapatkan dari proses pengumpulan data kemudian di analisis oleh surveilans dibantu oleh seorang petugas IT Puskesmas Bangsal dengan menggunakan computer, namun analisis data terbatas pada pembuatan tabel (seperti yang tercantum pada tabel 1.1) dan grafik (seperti yang tercantum pada grafik 1.2) berdasarkan pada waktu, umur pasien dan jenis kelamin pasien. 
Tabel 1. Data Sebaran Kasus COVID-19 di Kecamatan Bangsal Kabupaten Mojokerto pertanggal 11 Mei 2020 s/d 11 Agustus 2020

\begin{tabular}{|c|c|c|c|c|}
\hline No. & Desa & Konfirmasi & Konfirmasi Sembuh & $\begin{array}{l}\text { Konfirmasi } \\
\text { Meninggal }\end{array}$ \\
\hline 1. & Sumbertebu & 15 & 15 & 0 \\
\hline 2. & Kutoporong & 4 & 4 & 0 \\
\hline 3. & Pacing & 2 & 2 & 0 \\
\hline 4. & Ngrowo & 6 & 6 & 0 \\
\hline 5. & Gayam & 3 & 3 & 0 \\
\hline 6. & Salen & 4 & 4 & 0 \\
\hline 7. & Kedunguneng & 1 & 1 & 0 \\
\hline 8. & Pekuwon & 3 & 3 & 1 \\
\hline 9. & Peterongan & 5 & 4 & 0 \\
\hline 10. & Sidomulyo & 4 & 4 & 0 \\
\hline 11. & Ngastemi & 7 & 7 & 0 \\
\hline 12. & Bangsal & 6 & 4 & 1 \\
\hline 13 & Puloniti & 1 & 1 & 0 \\
\hline 14. & Mojotamping & 3 & 3 & 0 \\
\hline \multirow[t]{2}{*}{15.} & Sumberwono & 1 & 1 & 0 \\
\hline & Total & 66 & 62 & 2 \\
\hline
\end{tabular}

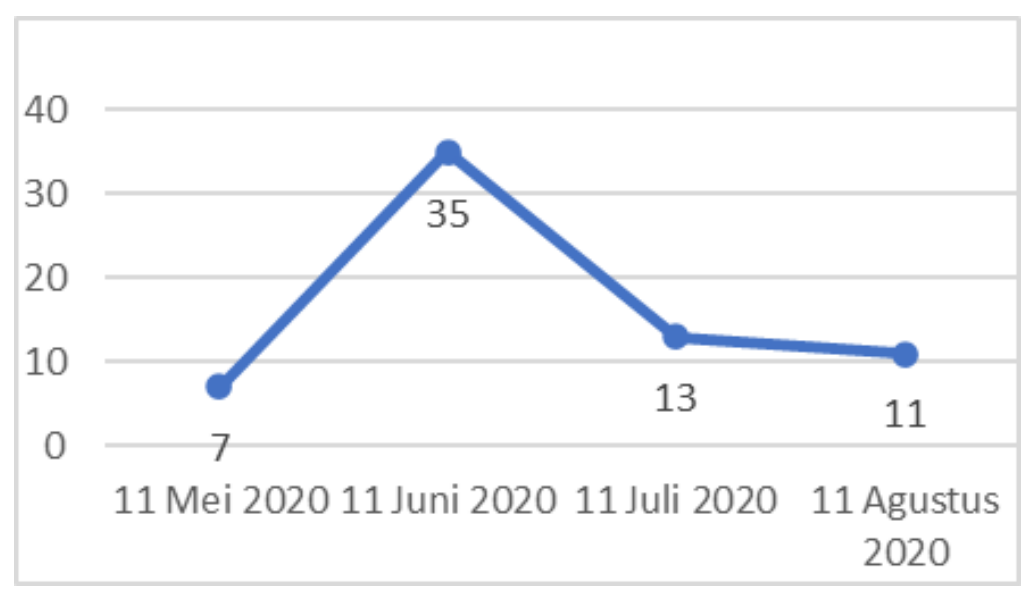

Gambar 1. Grafik Persebaran Kasus COVID-19 di Kecamatan Bangsal pada bulan Mei 2020 s/d Agustus 2020

Walaupun analisis terbatas hanya pada pembuatan tabel dan grafik namun, analisis dilakukan setiap bulan untuk mengetahui peningkatan dan penurunan jumlah kasus sehingga dapat dilakukan segera tindakan yang dibutuhkan.

\section{Pelaporan Data}

Pelaporan adalah catatan yang memberikan informasi tentang kegiatan tertentu dan hasilnya disampaikan ke pihak yang berwenang atau berkaitan dengan kegiatan tertentu. Data yang telah direkap maupun dianalisis oleh surveilans Puskesmas Bangsal dilaporkan ke Dinas Kesehatan Kabupaten setiap hari atau mingguan, maupun bulanan. Alur pelaporan dari Puskesmas Bangsal ke Dinas Kesehatan Kabupaten/Kota, seperti yang terlihat pada gambar berikut : 


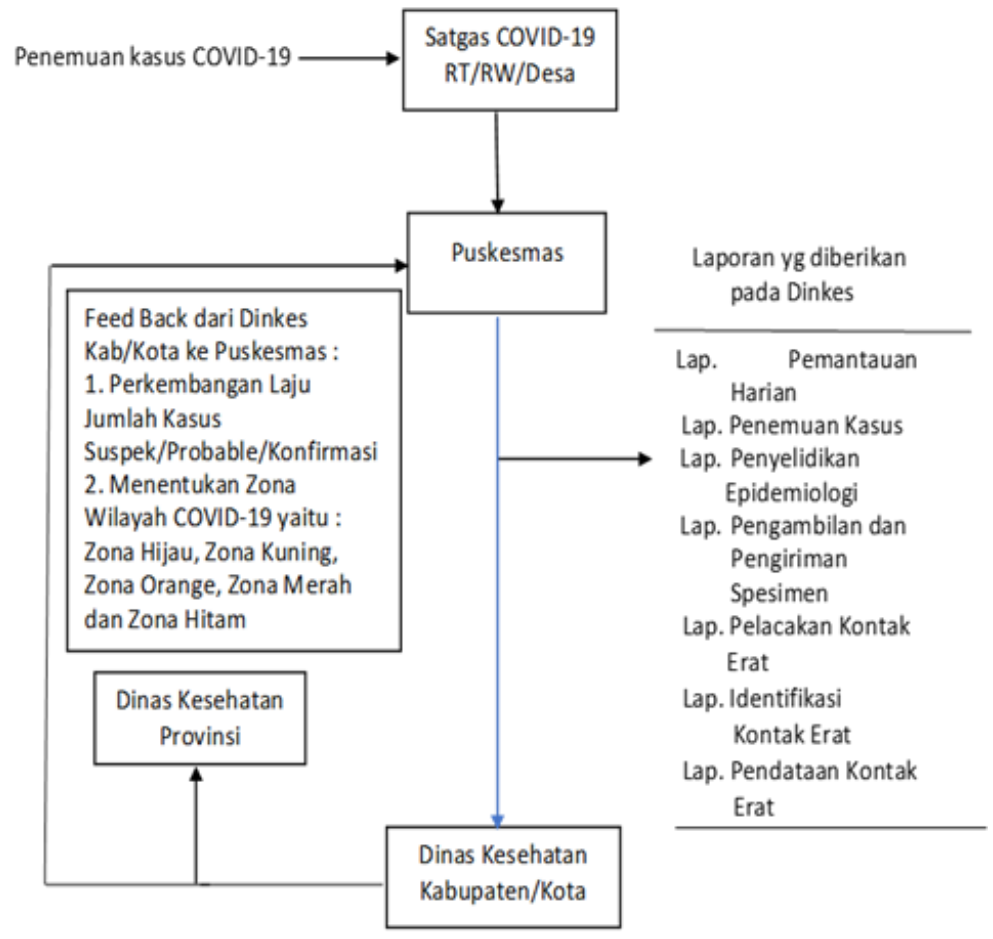

Gambar 2. Alur pelaporan dari Puskesmas Bangsal ke Dinas Kesehatan Kabupaten/Kota

\section{Gambaran Output}

\section{Informasi}

Informasi didapatkan dari hasil kegiatan yang telah dilakukan oleh petugas surveilans Puskesmas Bangsal selama menjalankan program. Informasi tersebut berguna untuk perkembangan program kegiatan pencegahan dan pengendalian

COVID-19 kedepannya agar surveilans bisa melakukan program dengan lebih benar. Berdasarkan hasil wawancara, Informasi berasal dari hasil analisis data, maka jika analisis data dilakukan dengan benar dan rinci akan menghasilkan sebuah informasi yang lengkap dan berguna.

\section{Indikator Kinerja Surveilans}

Indikator kinerja didefinisikan sebagai alat ukur yang digunakan untuk menentukan derajat keberhasilan organisasi dalam mencapai tujuannya. Kinerja surveilans COVID-19 di Puskesmas Bangsal dapat dikatakan berhasil karena dalam beberapa bulan program-program yang dilakukan untuk pengendalian dan pencegahan COVID-19 terbilang lancar dan sedikit kendala, namun tidak menjadikan program tidak berjalan.

\section{Hambatan dan Rekomendasi Pencatatan dan Pelaporan di Puskesmas Bangsal}

Jumlah surveilans di Puskesmas Bangsal hanya satu orang yang merangkap untuk program surveilans lainnya dan juga merangkap sebagai petugas pencatatan dan pelaporan yang terkadang timbul adanya penumpukan tugas sehingga menyebabkan pendataan dan pelaporan terlambat. Sebaiknya Puskesmas Bangsal dapat menambah jumlah surveilans dan petugas Pencatatan pelaporan yang berbeda sehingga tugas dari masingmasing tidak tertumpuk dan tidak lagi terjadi keterlambatan.

Saat proses pengumpulan data sering didapatkan orang dengan COVID-19 maupun bergejala COVID-19 menolak untuk didata dikarenakan masih kurangnya informasi benar yang didapatkan. Hal tersebut menyababkan terhambatnya proses pengumpulan data hingga proses pelaporan data. Sebaiknya surveilans dan Satgas COVID-19 Kecamatan Bangsal lebih aktif memberikan informasi kepada masyarakat agar tidak mudah mempercayai berita yang salah dan mencari berita di media yang dapat dipercaya.

Analisis data yang COVID-19 yang dilakukan oleh surveilans terbatas pada pembuatan tabel dan grafik yang berpedoman menurut waktu, umur dan jenis kelamin. Sebaiknya dilakukan analisis data dengan pembuatan tabel dan grafik yang lebih rinci sehingga didapatkan informasi yang lebih jelas dan akurat. 


\section{KESIMPULAN}

Pencatatan dan pelaporan yang dilakukan oleh Puskesmas Bangsal telah sesuai dengan pedoman KepMenkes HK.01.07/2020. Pencatatan kasus COVID-19 dilakukan dengan menggunakan form yang telah ditetapkan oleh Kementrian Kesehatan Republik Indonesia, sedangkan untuk pelaporan terdapat beberapa macam antara lain laporan penemuan kasus, laporan pengiriman dan pemeriksaan spesimen, laporan penyelidikan epidemiologi dan laporan pemantauan kontak erat.

Hambatan yang terjadi saat proses pencatatan dan pelaporan terjadi pada surveilans (Input), pengumpulan data dan analisis data (process). Hambatan diharapkan dapat di selesaikan agar proses pencatatan dan pelaporan tidak terkendala sehingga informasi yang didapatkan akurat dan dapat disampaikan ke masyarakat.

\section{ACKNOWLEDGEMENT}

Terimakasih kepada pihak yang sudah mendukung saya, terutama yang selalu mendukung saya selama saya melakukan penelitian ini, khususnya saya ucapkan terimakasih banyak kepada pihak Puskesmas Bangsal yang berada di Kecamatan Bangsal Kabupaten Mojokerto yang telah bersedia menerima saya untuk melakukan penelitian disana.

\section{REFERENSI}

Brooks, Geo, Karen C Carroll, Janet Butel, and Stephen Morse. 2012. Jawetz Melnick \& Adelbergs Medical Microbiology 26/E. Blacklick: McGraw-Hill Publishing. https://public.ebookcentral.proquest.com/choice/publicfullrecord.aspx?p=4958514 (January 31, 2021).

Coronaviridae Study Group of the International Committee on Taxonomy of Viruses. 2020. "The Species Severe Acute Respiratory Syndrome-Related Coronavirus: Classifying 2019-NCoV and Naming It SARS-CoV2." Nature Microbiology 5(4): 536-44.

Huang, Chaolin et al. 2020. "Clinical Features of Patients Infected with 2019 Novel Coronavirus in Wuhan, China." The Lancet 395(10223): 497-506.

KMK No. HK.01.07-MENKES-413-2020 Ttg Pedoman Pencegahan Dan Pengendalian COVID-19.Pdf.”

Lapostolle, Frédéric et al. 2020. "Impact of the COVID-19 Epidemic on the Incidence of Acute Myocardial Infarction in Seine-Saint-Denis." La Presse Médicale Open 1: 100002.

Satgas COVID19. 2020a. "Peta Sebaran." Peta Sebaran. https://covid19.go.id/peta-sebaran (November 18, 2020).

Satgas COVID 19. 2020b. "Peta Sebaran." Peta Sebaran. https://covid19.go.id/peta-sebaran (November 18, 2020).

Satgas COVID19 Jatim. 2020. "PETA SEBARAN COVID-19 JATIM." PETA SEBARAN COVID-19 JATIM. http://infocovid19.jatimprov.go.id.

Satgas COVID19 Kota Mojokerto. 2020. "Status Covid-19 Kota Mojokerto.” PETA SEBARAN COVID-19 Kota Mojokerto. https://covid19.mojokertokota.go.id (November 18, 2020).

Suresh Kumar, Vishnu Charan et al. 2020. "Novelty in the Gut: A Systematic Review and Meta-Analysis of the Gastrointestinal Manifestations of COVID-19." BMJ Open Gastroenterology 7(1): e000417.

Susilo, Adityo et al. 2020. "Coronavirus Disease 2019: Tinjauan Literatur Terkini." Jurnal Penyakit Dalam Indonesia 7(1): 45. 